\title{
Adichie's Purple Hibiscus and the Issue of Feminism in African Novel
}

\author{
Ibeku Ijeoma Ann \\ Federal University Oye-Ekiti, Ekiti State, Nigeria
}

\begin{abstract}
Adichie's Purple Hibiscus is a feminist work that challenges the dehumanizing tendencies of the menfolk as evident in the character of Mama (Beatrice Achike) who eventually exposed the African conception of an ideal woman who keeps dumb even in the face of humiliation, victimization, and brutality so as to be perceived as a good woman. We will make a resounding case to portray that Achike belongs to the category of liberal feminism. However, as events unfolds, she was forced by situations beyond her control to respond and go radical in order to crush anything that stands in her way to happiness. Efforts will be made to show how African women are rated based on the real and good women as represented by Ifeoma and Beatrice Achike respectively. This essay in exploring the different tenets of feminism will acknowledge that radical feminism is an off shoot of violence. We shall argue that radical feminism is a radical reaction to dehumanization, humiliation, and violence. This study seeks to address the issue of feminism and how characters subject to series of humiliation that leads to a radical approach to gain their freedom.
\end{abstract}

Keywords: feminism, humiliation, subjugation, Catholic, fanatic, patriarchy, real woman, good woman, Africa

\section{Introduction}

Chimamanda Ngozi Adichie has distinguished herself as one of Nigerian's female writers. She has won so many awards: The Prestigious Orange Broadband Prize for fiction for her second novel Half of a yellow sun (2006), winner of 2008 MacArthur Foundation Fellowship, and the 2005 Commonwealth Writers Prize for Purple Hibiscus. She is the author of Purple Hibiscus (2003), a collection of Short Stories, The Thing Around Your Neck, and Americanah (2013), her latest novel. Her works have been translated into thirty languages and also appeared in various publications like The O. Henry Prize Stories (2003), The New Yorker, Granta, the Financial Times, Zoetrope, and Farafina magazine.

Adichie focuses her attention on women and what they go through in life, their love for the family, respect for their husbands even when they treat them shabbily, and how some of them were able to say no to all forms of violence or subjugation by the menfolk. Udumukwu in his introduction to his book, Signature of Women, affirms:

There is a sharp contrast between the real woman in postcolonial Africa. Far from being the source of comfort and rest (the sweet mother as she is perceived in popular imagination), the "good” woman in sub-Saharan Africa happens to be that woman who suffers the effects of oppression, and neglect; and who must maintain a silence and passivity in order to remain good. Silence and passivity are two principal features of the good woman. In the media presentation of images

Ibeku Ijeoma Ann, Ph.D. candidate, assistant lecturer, Federal University Oye-Ekiti. 
from troubled regions of Africa, for instance, it is this "good" woman who bears the wicked children of war and disaster. Apart from being passive and silent in the face of radical change, she is also the embodiment of culture and tradition. The important issue, however, is that her passivity and docility have turned out to be potent fodder for her objectification by patriarchy. In other words, she is good because she naturally fits into the mould shaped for her by patriarchy. (Udumukwu, 2007, p. 3)

Adichie in her novel presented two types of women; the good woman (Mama) and the real woman (Aunty Ifeoma). Mama even when her life was endangered to the extent of losing her pregnancy endured her husband's maltreatment but Ifeoma is a kind of woman who is not afraid of anyone and will speak up when things are going wrong. She tactically presented Mama as quiet and obedient at the beginning of the novel but she became radical towards the end of the novel to show that she can react when pushed to the wall as will be discussed in some details presently.

The novel has received wide range of criticism as a result of its significance to the Nigerian novel. Ranti in his review praises the novel for bringing into the world of the traditional Igbo women and the events that took place during the Nigeria military regime. She affirms that the novel is "a complex picture of a man struggling with his demons, taking out his struggles on those he loves: his wife, Beatrice, his son, Jaja, and Kambili, (his daughter, the protagonist of the novel)" (Ranti, 2012, p. 1). Daniel Massa described Purple Hibiscus as focusing its attention on "love, cultural dislocation, political oppression, and domestic violence in their search for personal freedom” (Commonwealth news).

Brenda Cooper is of the notion in Adichie's Purple Hibiscus who "strives for a holistic vision which integrates Igbo customs and language with catholic ritual and which incorporates men into gender politics and embraces the literary traditions of her elders_Chinua Achebe, Ngugi Wa Thiong and Alice” (Cooper, 2012, p. 1-12). Most critics see Adichie as following the foot prints of Chinua Achebe because of her use of history in her writings. Chinua commented in one of her books, Americanah and said that "Adichie came almost fully made” (Chinua, 2011, p. 1).

Onukaogu and Onyerionwu are of the views that Purple Hibiscus is a feminist novel and based their argument on what Adichie said as being a "happy feminist" and consider it as being

very strategic in the criticism of her work, on which her feminist temperament reflects in its fullness for Adichie’s prose reveals that she is a synthesis of virtually every feminist tenet; even though the element of subtlety is strong in her narrative. (Onukaogu \& Onyerionwu, 2010, p. 195)

It is from here that this study will take its stand.

\section{Feminism and the African Novel}

Feminism is derived from the word "femina" which means woman. Therefore, it will be pertinent to state that feminism is women-oriented and concentrates on issues that concerns women. It is a literary movement that tends to bring about a change in the society especially on how women are treated; it tries to discourage discrimination and humiliation on women; it focuses its attention on emancipation of women. Lots of emphasis has been made on feminism and its stand in the African novel. Women are often relegated to the background and decisions made by men without their consent. Most African novels present female characters as sex objects, inferior beings, and those who must obey the rules made by men. Feminism has been described as having many faces based on the fact that it varies with circumstances surrounding it which can be cultural or historical. Whatever stands one takes, it will revolve around the gap between men and women. 
Ogunyemi is among the scholars that would not want to associate themselves with feminism and derives their own words. She prefers using womanism. She defined feminism as movement that:

smacks of rebelliousness, fearlessness, political awareness of sexism and an unpardonable (from the male view point) drive for equality and equity between sexes. It therefore instills fear in men though it thrills many women. The radical feminist can go as far as doing without the macho male to enjoy her liberty. (Ogunyemi, 1988, p. 61)

She posits that "Womanism, with its myriad manifestations, is therefore a renaissance that aims to establish healthy relationships among people, despite ethnic, geographical, educational, gender, ethical, class, religious, military and political differences” (Ogunyemi, 1985, p. 123).

On the same note, she describes Womanism as

the Nigerian woman writer who is constantly aware of the negative connotations of feminist; the fear of being accused by the Nigerian males of allying with the white outsider has turned most Nigerian women writers towards womanism; a black outgrowth from feminism. (Ogunyemi, 1985, p. 124)

She further states that

Womanism is black centered, it is accommodationist. It believes in the freedom and independence of women like feminism; unlike radical feminism, it wants meaningful union between black women and black men and black children and will see to it that men begin to change from their sexiest stand. (Ogunyemi, 1988, p. 65)

By defining both terms, she tries to take a stand on where she belongs.

Similarly, Alice Walker prefers to use womanism and defines it as "a black feminist or feminist of colour...committed to survival and wholesomeness of entire people, male and female...not a separatist, except periodically, for health...love struggle, loves the folk, loves herself...” (Walker, 1984, pp. xi-xii)

Obioma Nnaemeka also presents her version of feminism which she prefers to be called "Nego-feminism" and contends that:

Nego-feminism is the feminism of negotiation; second, nego-feminism stands for no-ego feminism. In the foundation of shared values in many African cultures are the principles of negotiation, give and take, compromise and balance... African feminism (or feminism as I have seen it practiced in Africa) challenges through negotiations and compromise. It knows when, where, and how to detonate patriarchal land mines. In other words, it know when, where, and how to negotiate with or negotiate around patriarchy in different contexts. (Nnaemeka, 1991, pp. 377-378, as cited in Walker, 1984)

Acholonu uses the term "Motherism” as “Africa's alternative to Western Feminism” (Acholonu, 1995, p. 3). She believes that a motherist is a humanist and environmentalist. She recognizes that women fell in love and "respects the interconnectedness of all life, the ecosystem and the entire human race" (Acholonu, 1995, p. 112). Alice Walker prefers to be called a womanist and upholds that "a womanist is a black feminist or feminist of colour-committed to the survival and wholeness of the entire people, male and female... (but who) loves herself. Regardless” (Davies \& Graves, 1995, p. 5, as cited in Walker, 1984).

Ogundipe-Leslie views that

African feminism for me, therefore, must include issues around the woman's body, her person, her immediate family, her society, her nation, her continent and their locations within the international economic order because those realities in the international economic order determine African politics and impact on the women. There is no way we can discuss the situation of the African woman today without considering what the IMF policies and World Bank are doing to her status and her conditions. (Ogundipe-Leslie, 1984, p. 228) 
She later disassociates herself from the word "feminism" and prefers using STIWANISM because the issues that revolves around using feminism. It means Social Transformation Including Women in Africa and she postulates that it "is about the inclusion of African women in the contemporary social and political transformation in Africa” (Ogundipe-Leslie, 1984, p. 230).

It is obvious from the above that most women writers do not want to associate themselves with feminism but there are some that accepts it, to the extent of calling themselves "happy feminist" in the likes of Chimamanda Adichie and Ama Ata Aidoo in a keynote address in which they gave the opinion that

when people ask me rather bluntly every now and then whether I am a feminist, I not only answer yes, but I go on to insist that every woman and every man should be a feminist- especially if they believe that Africans should take charge of African land, African wealth, African lives and the burden of African development. It is not possible to advocate independence for the African continent without also believing that African women must have the best that the environment can offer. For some of us, this is the crucial element in our feminism. (Adichie, 2007, p.47)

Elizabeth Fox-Genovese in her essay, "Placing Women's History in History" argues that feminism places women at the center of history by recognizing their peculiar roles and contribution in the shaping of history (Fox-Genovese, 1982, p. 29). Filomena Steady views that feminism is about the issues that affect the African women and they are out in liberating themselves in order to be free.

Charlotte Bunch in his opinion states the importance of theory in feminism when he states that:

Theory enables us to see immediate needs in terms of long-range goals and an overall perspective on the world. It thus gives us a framework for evaluating various strategies in both the long and the short run and for seeing the types of changes that they are likely to produce. Theory is not just a body of facts or a set of personal opinions. It involves explanations and hypotheses that are based on available knowledge and experience. It is also dependent on conjecture and insight about how to interpret those facts and experiences and their significance. (Hooks, 1984, p. 30)

Nnolim took a different stand in his definition of Feminism and sees it as an image of "a house divided" (Nnolim, 2003, pp. 248-261). He views that women are fighting themselves through the ways they present their female characters in most of their novels. M. J. C. Echeruo makes a critical assertion to the task that lies ahead for African Feminism when he states that the task that remains is for African Feminism to establish the general and theoretical bases for making the hard choices which Dr. Acholonu says lie ahead: between a radical dismantling of patriarchy and a zealous movement or reconciliation and compromises. It is a task to keep African women and all those others who write on the African condition busy for a long, long time.

Udumukwu in his book Signature of women affirms:

Women's distinctive approach to various situations and problems posed by life and living in Africa has drawn increasing attention in recent times. The latter part of the twentieth century witnessed the growth of an enormous volume of literature written by women and for women. This literature has underscored the view that the images of women usually found in literature have been created by men without any true reference to the peculiarity of women's experiences. In African literature, for instance, men have mostly written of women in their own context as sexual objects, as mothers of children as daughter and as mistresses and goddesses. These female stereotypes turn out to conform with the traditional patriarchal view of the woman as inferior to man. (Udumukwu, 2007, p. 5)

This was the situation in Africa before women started writing and concentrated on a common theme which Udumukwu refers to as "the recognition of the need to place women at the Centre rather than at the periphery" (Udumukwu, 2007, p. 5).

Kate Millet, who is a radical figure in second war of feminism, views that Patriarchy subordinate the 
female to the male, it treats the female as inferior to male and this power is exerted directly or indirectly, in civil and domestic life to constrain women...Millet recognizes that women as much as men perpetuate these attitudes and the action out of these sex roles in the unequal and repressive relations or dominations and subordination in what Millet calls "sexual politics" (Millet, 1973, p. 173) .

Nnolim sees feminism as an image of "a house divided". He views that women are fighting themselves through the ways they present their characters in their novels "With so many African female writers unsure of the future of feminism and of their rebellious female characters that they often destroy or make mad, one could predict a bleak future for the movement” (Nnolim, 2003, p. 19). Chukwuma in response to the above assertion by Nnolim affirms "Nnolim's fear of equality between the sexes as a result of such female exposure and push is natural for one who all his life has been on the supremacy ladder, and is now in defense of his gender" (Chukwuma, 1994a, p. xxii). She further states "the women turn out to be the foundation on which the house rests” (Chukwuma, 1994a, p. xiii). In the same vein, Akachi Ezeigbo in response to Nnolim's assertion posits: "the beauty of existence is seen in controversy, contention, even in discordant voices which would definitely end harmoniously, after everyone has probably had a say. If it does not, then people will have to 'agree to disagree'” (Snail-Sense, p. 40, as cited in Ezeigbo, 1991). An example of "a house divided" can be found in Onwueme's "Tell It To Women" when Yemoja, a female character laments on how she is treated: "If I am not trapped in a husband's chain or father's chain, I'm trapped in another woman's chain. Where is the way? Where is the free—free—freedom that these women talk about? (Onwueme, 1994, p. 13).

Maduka in a paper titled "Feminism and the Nigerian Female Critic: A Metacritical Statement" believes that

Feminism is systematically assuming a strategic position in Nigerian critical discourse. This is largely due to the emergence of female academics/ critics who have consistently used their works to challenge the dehumanizing tendencies of the patriarchal socio-political institutions in the country. (Maduka, 2001, p. 227)

Stegeman believes that feminism is a course embarked upon by women and she views that

the new woman who promotes a theory of personhood where the individual exists as an independent entity rather than a group member, where she is defined by her experiences rather than her kinship relations, where she has a responsibility to realize her potential for happiness rather than quantitative financial worth, and where she must reason about her own values, rather than fit into stereotyped traditions. (Stegeman, 1974, p. 90)

Similarly, Adichie affirms

An integrated house constructed on a foundation, consisting of a myriad of African feminist thoughts, is expected to weather the raging storms and robustly play out amidst panoply of concepts and dialectics. And the feminist current remains relevant in this female phase as the women struggles with the stress-related thing around their neck that nearly chokes her before she falls asleep. (Adichie, 2006, pp.119, 125)

\section{Feminism as Seen in the Novel}

Adichie presented the two different types of feminism: African feminism which is often seen as being liberal and tolerates men and Radical feminism which uses violence in order to gain their freedom. The novel made it clear that Radical feminism is usually a reaction to violence. It is a measure taken by the victimized to gain his/her freedom. At the beginning of the novel, Mama (Beatrice Achike) tolerates the brutality and victimization from her husband as an African woman so as to be regarded as a good woman for the sake of her 
society. In African tradition, it is a taboo to be a divorcee. From the opening of the novel, one can clearly predict the type of husband/father. Eugene Achike will be to his household. Adichie started the novel in this way to clearly describe the family as will be seen all through the novel. Kambili's voice is used in telling us the events as they unfold and the opening of the novel through her voice made us to know the kind of father she has when she posits

Things started to fall apart at home when my brother, Jaja, did not go to communion and Papa flung his heavy missal across the room and broke the figurines on the "étagère". We had just returned from church. Mama placed the fresh palm fronds, which were wet with holy water, on the dining table and then went upstairs to change. Later, she would knot the palm fronds into sagging cross shapes and hang them on the wall beside our gold-framed family photo. They would stay there until next Ash Wednesday, when we would take the fronds to church, to have them burned for ash. Papa, wearing a long, gray robe like the rest of the oblates, helped distribute ash every year. His line moved the slowest because he pressed on each forehead to make a perfect cross with his ash-covered thumb and slowly, meaningfully enunciate every word of “dust and unto dust shall you return”. (Adichie, 2003, p. 5)

Eugene from the opening of the novel is seen as an ardent Christian whose life does not reflect Christianity at home. In catholic tradition, the missal is a sacred book that contains the words of God and for him not to have any regard for it clearly depict that he is just a church goer and not a true Christian as we are meant to believe. It is assumed that he should have a forgiving heart for the sake of the word of God he has just heard from the church because through Kambili, we understood that they just came back from church and she showed us how committed her father is in church by helping to distribute ash in church, a privilege for selected few in catholic traditions.

The breaking of the figurine is very significant in the novel in the sense that it serves as a source of consolation whenever Mama is heartbroken, she cleans it each time her husband beats her. Kambili through whose eyes we see the characters said

I meant to say I am sorry Papa broke our figurines, but the words came out were, "I'm sorry your figurines broke, Mama”. She nodded quickly, and then shook her head to show that the figurines did not matter. They did, though. Years ago, before I understood, I used to wonder why she polished them each time I heard sounds from their room, like something banged against their door. Her rubber slippers never made a sound on the stairs, but I knew she went downstairs when I heard the dining room door open. I would go down to see her standing by the étagère with a towel soaked in soapy water. She spent at least a quarter of an hour on each ballet-dancing figurine. There were never tears on her face. The last time, only two weeks ago, when her swollen eye was still the black-purple colour of an overripe avocado, she had rearranged them after she polished them. (Adichie, 2003, pp. 18-19)

As the figurine is broken, one will wonder how she will deal with her emotions whenever there is a quarrel between them. It is obvious that Beatrice has no other choice but to look for means of dealing with the pains and the humiliation that she gets from her husband. It is possible that Adichie makes the breaking of the figurine possible at the beginning of the novel in order to look for a way to stand up and fight for her right. Even when her daughter asked if she will replace it, she said no. This is a deliberate attempt by the author to make sure that the woman does not always look for means of hiding the humiliation and subjugation she passes through but rather to look for a way to say no to all forms of ill treatment as evident in the novel. Beatrice is so much attached to her marriage with Eugene Achike because she felt he is a source of spiritual, emotional and physical strength. She felt that Eugene would have listened to his kinsmen into taking another wife since she could only give birth to just two children. Leaving the marriage for her will make her an ingrate, so, she stays against all odds to honour the man that honoured her. It is obvious that their faith in the Catholic church made 
her to believe that divorce is not an option in marriage but rather, marriage should be for better for worse and even the African community where she comes from sees the good woman as one who "suffers the effects of oppression, and neglect; and who must maintain a silence and passivity in order to remain good. Silence and passivity are two principal features of a good woman” (Udumukwu, 2007, p. 3) as Udumukwu acclaimed in his book. He also presented a striking balance between a good woman and the real woman which can be likened to the character of Ifeoma who "even in the face of tyranny will not remain silent" (Udumukwu, 2007, p. 3). Beatrice is presented as an epitome of a good woman who tolerates all kinds of humiliation. She told her daughter how the villagers wanted her father to marry another wife when she couldn't give birth and as a result, she felt indebted to her husband no matter what happens even to the detriment of her life. She posits:

God is faithful. You know after you came and I had the miscarriages, the villagers started to whisper. The members of our "umunna" even sent people to your father to urge him to have children with someone else. So many people had willing daughters, and many of them were university graduates, too. They might have borne many sons and taken over our home and driven us out, like Mr. Ezendu's second wife did. But your father stayed with me, with us..."Yes” I said. Papa deserved praise for not choosing to have more sons with another woman, of course, for not choosing to take a second wife. But then, Papa was different. I wished that Mama would not compare him with Mr. Ezendu, with anybody; it lowered him, soiled him. (Adichie, 2003, p. 28)

This goes a long way to explain why Mama would stick to her husband even if it means death, her daughter saw reasons with her and also was grateful that her father is a good man, though she felt that comparing her father to some men as Mama did is bringing down his reputation.

One can assume that he will be lenient on his wife but the reverse is the case as he made it obvious for his children to notice he has no regard for their mother. When Kambili informed Jaja that their mother is pregnant, it is expected that he should be happy as children always do when they are aware that they will have a baby in their family but Jaja told her that they will have to protect the baby—-this is ridiculous. Kambili said "Mama is pregnant... and will be due in October". Jaja closed his eyes for a while and then opened them. "We will take care of the baby; we will protect him. I knew that Jaja meant from Papa, but I did not say anything about protecting the baby. Instead, I asked, “How do you know it will be a he?”(Adichie, 2003, p. 31).

It is naturally believed that a pregnant woman is fragile and should be handled with care but Mama's case was different as a result of the kind of man she got married to. She was not allowed to take decisions on her own, Papa also dictates for her as can be seen in the novel when she felt like staying back in the car because of her condition but he bluntly refused. It has become a tradition for them to visit Fr. Benedict after mass.

“Let me stay in the car and wait, biko,” Mama said, leaning against the Mercedes. "I feel vomit in my throat.” Papa turned to stare at her. I held my breath. It seemed a long moment, but it might have been only seconds. Mama was looking down; her hands were placed on her belly, to hold the wrapper from untying itself or to keep her bread and tea breakfast down. "My body does not feel right." she mumbled. "I asked if you were sure you wanted to stay in the car.” Mama looked up. “I'll come with you. It's really not that bad.” Papa's face did not change. He waited for her to walk towards him, and then he turned and they started to walk to the priest's house. Jaja and I followed. I watched Mama as she walked. Till then I had not noticed how drawn she looked. Her skin, usually the smooth brown of groundnut paste, looked like the liquid had been sucked out of it, ashen, like the colour of cracked harmattan soil. Jaja spoke to me with his eyes: what if she vomits? I would hold up my dress hems so Mama could throw up into it, so we wouldn’t make a big mess in Father Benedict's house. (Adichie, 2003, pp. 37-38)

This goes a long way to show that her children are even aware of who their father is and his style of dictating for everyone even at their own detriment. 


\section{For Ogundipe-Leslie,}

African Feminism for me, therefore, must include issues around the woman's body, her person, her immediate family, her society, her nation. Her continent and their locations within the international economic order because those realities in the international economic order determine African politics and impact on the women. There is no way we can discuss the situation of the African woman today without considering what the IMF policies and the World Bank are doing to her status and conditions (Ogundipe-Leslie, 1984, p. 228).

Based on this explanation, one can succinctly say that Mama has been violated in different ways by her husband. She is the type of woman that feels that her marriage to her husband is worth all the troubles she goes through and sees it as a privilege considering the fact that he could have married another wife as suggested by his kinsmen and so, Ogundipe-Leslie's assertion may not really bother her but it is just a reflection of what is happening to her as we were told by Kambili.

I heard the door open. Papa's gait on the stairs sounded heavier, more awkward, than usual. I stepped out of my room just as Jaja came out of his. We stood at the landing and watched Papa descend. Mama was slung over his shoulder like the jute sacks of rice his factory workers bought in bulk at the Seme Border. He opened the dining room door. Then we heard the front door open, heard him say something to the gate man, Adamu. “There's blood on the floor," Jaja said. "I'll get the brush from the bathroom.” We cleaned up the trickle of blood, which trailed away as if someone had carried a leaking jar of red water colour all the way downstairs. Jaja scrubbed while I wiped. Mama did not come home that night, and Jaja and I had dinner alone. We did not talk about Mama. (Adichie, 2003, p. 41).

This violent action by Eugene on his wife is against Ogundipe-Leslie's assertion. He has violated and caused harm on his wife's body to the extent of killing an unborn child which is against humanity and also, God whom he claimed to worship and adore. This kind of situation contradicts the fate which his Catholic doctrine professes. As a good woman who must protect the image of her husband, she came back from the hospital as if nothing happened and told her kids that

“There was an accident, the baby is gone,” she said. I moved back a little, stared at her belly. It still looked big, still pushed at her wrapper in a gentle arc. Was Mama sure the baby was gone? I was still starring at her belly when Sisi came in”. As always, she can't blame her husband for all the harm he has caused and as such, dare not tell her kids about it, though they know the truth. (Adichie, 2003, p. 42)

In contrast, Adichie presented another kind of woman whom Udumukwu referred to as the "real woman". Aunty Ifeoma is totally different from Mama, she stand up for her right no matter the consequences. She is of the opinion that things are not working the way. It should in the school and can't keep quiet for it to get worse. She complained to her colleague:

We cannot keep quiet, sit back and let it happen, "mba”. Where else have you heard of such a thing as a sole administrator in a university?” Aunty Ifeoma said, leaning forward on the stool. Tiny cracks appeared in her bronze lipstick when she pursed her lips. "A governing council votes for a vice chancellor. That is the way it has worked since this university was built, that is the way it is supposed to work, oburia (meaning-it is not like that)?” the woman looked off into the distance, nodding continuously in the way that people do when searching for the right words to use. When she finally spoke, she did so slowly, like someone addressing a stubborn child. "They said there is a list circulating, Ifeoma, of lecturers who are disloyal to the university. They said they might be fired. They said your name is on it.” She replied her colleague and said "I am not paid to be loyal. When I speak the truth, it becomes disloyalty. (Adichie, 2003, pp. 227-228)

Ifeoma is an epitome of a real woman who stand up for her right despite the consequences, she refused to be intimidated by those who feels they are at the helm of affair and refused to keep quiet. She is very intelligent 
and can defend herself as such, wasn't afraid of losing her job. Even when she lost her job, she has started making plans on how to relocate to a society that will appreciate her real womanhood unlike Mama who is so glued to her marriage and saw it as a privilege to be married to Eugene Achike.

One can decide to give up on Mama because it is obvious she enjoys the treatment meted out on her by Eugene, she refused to stand up and say no to all forms of violent action by her husband. One can succinctly say that Mama is bound up in the marriage as a result of her faith in her religion and the culture of her people; the African woman is usually seen as an embodiment of her cultures and traditions and as such held bound by it. It is expected that Papa should have learnt his lessons after the first miscarriage and treats his wife with more care but he always behaves like someone tormented by the evil spirit, who after committing a crime, becomes sober and goes back to it again. After the second miscarriage, she was forced to run for her dear life as she narrated the ordeal to Ifeoma when she visited them at Nsukka unexpectedly.

"My doctor said there was nothing he could do to save it.” Mama shook her head slowly. A thin line of tears crawled down her cheeks as though it had been a struggle for them to get out of her eyes. "To save it?” Aunty Ifeoma whispered. “What do you mean?” “I was six weeks gone.” “Ekwuzina! Don’t say that again!” Aunty Ifeoma’s eyes widened. “It is true. Eugene did not know, I had not told yet told him, but it is true”. (Adichie, 2003, pp. 253-254)

Ifeoma was so furious when she heard what happened to her to the extent of losing a pregnancy, she couldn't take sides with her brother as one will think but insisted that she won't speak to his wife when he later called. Mama is the opposite of Ifeoma, she is totally against her brother's attitude of beating his wife and sees it as a sign of humiliation. She pleaded with Mama to spend some time with her before going back but, as always, she makes excuses for her husband and the need go back to him. Ifeoma compared her late husband and her brother when Mama was seriously making excuses for him and even told her that his money should not make her worship him like a god. She was so furious when Mama started giving her instances of what Eugene did for the people in his village but she bluntly told her that it is far from what they are saying. She was so pissed off when she gave reasons for her husband's behavior. She said

\footnotetext{
"Eugene has not been well. He has been having migraine and fever," she said. "He is carrying more than any man should carry. Do you know what Ade’s death did to him? It is too much for one person." "Ginidi, what are you saying?" Aunty Ifeoma swiped impatiently at an insect that flew close to her ears. "When Ifediora was alive, there were times, nwunye $\mathrm{m}$, when the university did not pay salaries for months. Ifediora and I had nothing, eh, yet he never raised a hand to me." "Do you know that Eugene pays the school fees of up to a hundred of our people? Do you know how many people are alive because of your brother?" "That is not is not the point and you know it." "Where would I go if I leave Eugene's house? Tell me, where would I go?”. (Adichie, 2003, p. 255)
}

As always, she uses the above assertion to convince anyone that cares to listen, on the reason why she should accept all forms of violence from the husband. Eugene subjects his family to all forms of psychological trauma and it affected their psyche drastically. Kambili could not talk boldly with Amaka; she found out that their family is totally different from theirs as a result of her father's authoritative way of ruling the family. Eugene's abuse on his family ranges from psychological to physical which affected all the members of his family. Julia T. Wood gives the view that those who violate people do so "to gain or sustain self-esteem, to win the respects of others, to maintain control over people and situations” (Adichie, 2003, p. 294). Eugene ended up losing respect from his family, they are only afraid of him and does whatever they like when he is not around. They were banned from watching television, associating with their cousins and grandfather, and playing and even talking in the house. Their life was so regimented by their father's presence and they talk in whispers 
when he is around.

Beatrice's second miscarriage and constant beating by her husband is like the shot that broke the camel's back. She must have told herself that if she continues like this, Eugene may kill her one day and will still marry another wife. She made up her mind to forget what the church and her society will say if she kills the obstacle that stands on her way to freedom. It must have been a big battle before she made up her mind to do it. Sisi who we always see through the eyes of Kambili, cooking and taking good care of the house must have been angry with her master for constantly beating his wife and children but she can't do anything to salvage the situation or assist them because she is often regarded as a mere cook who should follow the order in the house and as such, can't contribute anything meaningful to the development of the family. She is like a watchdog that is always at home and sees everything that happens. The opportunity came when her madam confided in her and she offered to help. Jaja who is always being presented as a stubborn son who disobeys his father did not blink an eye but to stand in as the sacrificial lamb even when he is not the culprit. He promised to save their unborn baby from the whims of his father even when the baby is yet unborn. He must have been constantly devastated by his father's behavior and promised to do all he can to protect the women in his life-Mama and Kambili. He always takes responsibility of an offence committed by his sister in order to protect her from his father. It wasn't surprising to us when he gave himself as the culprit when his father died. He always compares himself to Obiora who is younger but takes care of his mother; he said "I should have taken care of Mama. Look how Obiora balances Aunty Ifeoma's family on his head, and I am older than he is. I should have taken care of Mama” (Adichie, 2003, p. 293). One can rightly say that if not for the autopsy conducted on his body, she would have kept everything to herself. She purposely refused to pick up the phone but when the caller persisted, she picked and announced to her children that:

"They did an autopsy," “They found the poison in your father's body.” She sounded as though the poison in Papa's body was something we all had known about, something we had put in there to be found, the way it was done in the books I read where white people hid Easter eggs for their children to find. "Poison?” I said. Mama tightened her wrapper, and then went to the windows; she pushed the drapes aside, checking that the louvers were shut to keep the rain from splashing into the house. Her movements were calm and slow. "I started putting the poison in his tea before I came to Nsukka. Sisi got it for me; her uncle is a powerful witch doctor. (Adichie, 2003, p. 295)

Beatrice has ceased to be the traditional good woman to a real woman who will not remain silent in the face of tyranny. It is obvious that she has endured a lot from his husband who refused to turn a new leave. She made up her mind to crush anything on his way to happiness not minding who. This is a deliberate attempt by Adichie in order to prove that those who choose a radical way to achieve their happiness must have given a warning sign before resorting to that way. Beatrice endured a lot from her husband but when it's obvious she can't keep on staying glued to him because she felt that he did her a favour by not marrying another wife who can give him more children. She refused to take into consideration what the church and the society will say because she believes that they could not tame Eugene and as such, damned their consequences. Her children did not blame her for killing their father except Kambili who objected to her method of killing because, they usually take a sip from their father's sip and would have been killed as well but their mother was wise enough to know when to use the poison.

Jaja who feels it's his responsibility to protect his mother and often compares himself with Obiora who is younger but takes proper care of his mother in the absence of his father did not hesitate to take responsibility of killing his father and was taken away by the police men. Kambili states 
The policemen came a few hours later. They said they wanted to ask some questions. Somebody at St Agnes Hospital had contacted them, and they had a copy of the autopsy report with them. Jaja did not wait for their questions; he told them he had used rat poison, that he put it in Papa's tea. They allowed him to change his shirt before they took him away. (Adichie, 2003, p. 295)

This will be for Jaja a way to make up all the times he has failed to protect his mother and sees it as an opportunity to make amends. Mama was so devastated when he was taken away and was depressed psychologically and physically, she talks sparingly and gazes into the thin air. Kambili reveals that

She has been different ever since Jaja was locked up, since she went about telling people she killed Papa...but nobody listened to her; they still don't. They think grief and denial—-that her husband is dead and that her son is in prison—have turned her into this vision of a painfully bony body, of skin speckled with blackheads the size of watermelon seeds... Most times, her answers are nods and shakes of the head....and often...she simply sat and stared. (Adichie, 2003, p. 296)

\section{Conclusion}

Adichie's Purple Hibiscus is a feminist work that challenges the dehumanizing tendencies of the menfolk. This was evident in the character of Mama (Beatrice) who undergoes series of humiliation, dehumanization, and denial from her husband. The novel showcased Mama as a good woman who tolerates everything from her husband and often consoles herself as a result of what the church and society will say. She felt that her marriage to Eugene is a favour considering the fact that he refused to listen to his kinsmen on the need to take another wife when she couldn't give birth after two children. One can ask whose fault because it is because it's obvious that she lost two pregnancies as a result of her husband's violent action and should be blamed for her inability to give birth to more children.

We also present two different types of women: the good and the real women as evident in the character of Mama and Aunty Ifeoma respectively. Ifeoma belongs to the group of lecturers who refused to keep silent over bad governance by the Vice Chancellor of the school where she lectures, she refused to be intimidated when she was informed that her name is on the list of those who are not loyal to the Vice Chancellor and will be sacked. While Mama was often subjected to all forms of humiliation but kept silent in order to be regarded as a good woman by the church and the society she lives in.

Adichie, also, presented the two different types of feminism viz: the Liberal and the Radical. Ifeoma was associated with the radical way of standing up for her right while Mama at the beginning of the novel was liberal but when it became obvious that her life is at risk, she dammed the consequences and went radical. This is a deliberate attempt by Adichie to prove that radical feminism is a reaction to some circumstances, she believes that one can't wake up and start crushing anything that stands in his/her way. It is often being prompted by situations that seem to overpower the person. Mama's radical way of ending her husband's life was prompted by his violent actions which she brought to an end by poisoning his tea.

\section{References}

Acholonu, C. (1995). Motherism: The Afro-centric alternative to feminism. Owerri: Afa.

Adichie, C. N. (2006). Half of a yellow sun. Lagos: Farafina.

Adichie, C. N. (2003). Purple hibiscus. Lagos: Farafina.

Bruner, C. H. (1983). Preface. In C. H. Bruner (Ed.), Unwinding threads: Writing by women in Africa. London: Heinemann.

Chukwuma, H. (1994a). The identity of self. In Feminism in African literature: Essays on criticism (pp. xiii-xxvii). Port Harcourt: Pearl; Publishers.

Chukwuma, H. (1994b). Feminism in African literature: Essays on criticism. Enugu: New Generation Books. 
Chukwuma, H. (1991). Feminism and femininity in African literature. MLAN, 298-311.

Chinweizu, M. (1990). Anatomy of female power: A masculinist dissection of patriarchy. Lagos: Pero.

Copnall, J. (2011, December, 16). Steak knife. The Times Literary Supplement, 20.

Cooper, B. (2012). Resurgent spirits, Catholic echoes of Igbo and petals of purple: The syncretised world of Chimamanda Ngozi Adichie’s purple hibiscus. In E. N. Emenyonu (Ed.), New novels in African literature today. Ibadan: HEBN.

Ezeigbo, T. A. (1991). Fact and fiction in the literature of the Nigerian civil war. Ojo: Unity.

Fox-Genovese, E. (1982). Placing women's history in history. New Left Review, 133, 5-29.

Hooks, B. (1984). Feminist theory: From margin to centre. Boston: South End Publishers.

Maduka, C. (2001). Feminism and the Nigerian female critic: A metacritical statement. In A. A. Akpuda (Ed.), Reconstructing the Canon: Festschrift in honour of professor Charles Nnolim (pp.227-242). Owerri: Skillmark Media.

Massa, D. (2006). Review of purple hibiscus by Chimamanda Ngozi Adichie: The aesthetics of commitment. Ibadan: Kraft Books. Millet, K. (1973). Sexual politics. New York: Avon.

Nnolim, C. (2003). A house Divided: Feminism in African Literature. In H. Chukwuma (Ed.), Feminism in African literature: Essays on criticism (pp. 252-265). Port Harcourt: Pearl Publishers.

Ogundipe-Leslie, O. (1984).African women, culture and another development. Journal of African Marxists 5, (35-36), 63-80.

Ogunyemi, C. O. (1985). Womanism: The dynamics of the contemporary black female novel in English. Chicago: University of Chicago Press.

Ogunyemi, C. O. (1988). Women and Nigeria literature. In Y. Ogunbiy (Ed.), Perspectives on Nigerian literature (pp. 60-67). Lagos: Guardian Books..

Onukaogu, A., \& Onyerionwu, E. (2010). Chimamanda Ngozi Adichie: The aesthetics of commitment and narrative. Ibadan: Kraft Books Ltd..

Onwueme , T. (1994). Tell it to women. Ibadan: Heinemann.

Rose, G. (1995). Making space for the female subject of feminism: The spatial subversion of Holzer, Kruger and Sherman. In S. Pile \& N. Thrift (Eds.), Mapping the subject: Geographies of cultural transformation (pp. 332-355). London: Routledge.

Selden, R. (1988). A reader's guide to contemporary literary theory. Brighton: The Harvester.

Stegeman, B. (1974). The divorce dilemma: The new woman in contemporary African novels. Critique: Studies in Modern Fiction, 90-92.

Udumukwu, O. (2007). Signature of women. Owerri: Onii Publishing House

Ranti, W. (2012). Review of Chimamanda Adichie's Purple Hibiscus. Retrieved from http://www.weaverpresszimbabwe.com/index.php/reviews/24-purple-hibiscus/73-review-of-purple-hibiscus-by-ranti-willia ms

Walker, A. (1984). In search of our mother's gardens. London: The Women’s Publishers.

Wood, J, T. (2009). Gendered lives: Communication, gender, and culture (8th ed.). Boston: Wadsworth. 